\title{
某工場製品倉庫乞の他に関する屋内気候に就て
}

正会員宮野秋 彥*

$\$ 1$ 緒言 建築物の屋内気候汇関する諸 問題の内でる湿度対策関しては未だ十分な 解明がなされていない。筆者は湿度対策検討 の基礎的資料を得るべく各種の建物に就て、 その屋内湿度分布並飞変動の実態を究明しつ つあるが、兹には䡠に行つた某工場の倉庫そ の他と関する測定結果の一部を報告する。 合、測定飞当つては東京工業大学齐藤幸男教

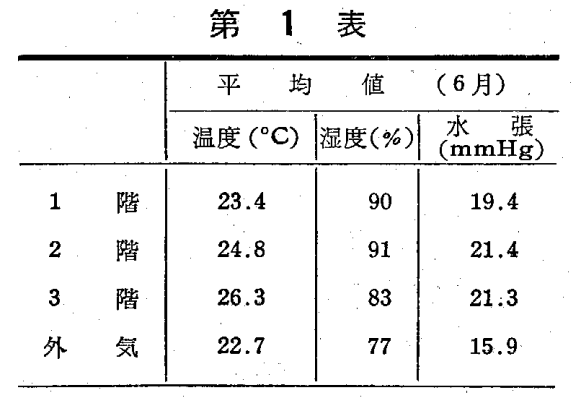

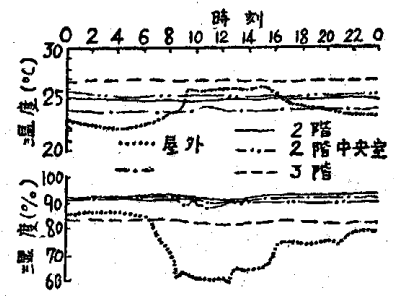

第 3 図

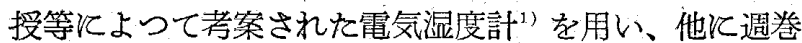
自記湿度計を併用した。

$\S 2$ 実測建物 測定の対象とした建物结、某夕バコ 製造工場の製品倉庫及び製品乾燥室である。

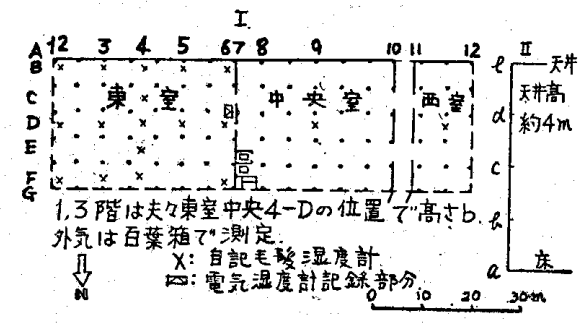

第 1 図

製品倉庫は第 1 図に示す如き東西に長い平面を有する 鉄筋コンクリート造 3 階建、建坪約 $2,800 \mathrm{~m}^{2}$ 、で、各階 共東西並に中央の三室飞分れて招り夫々南面には空をる たない。外壁外装は色モルタル吹付、内装はプラスタ吹 付、腰 $1 \mathrm{~m}$ 油性ペイント叙、天井は床版へプラスタ吹 付、床はモルタル仕上であ る。製品乾熉室は鉄筋コン クリート造、3 階建工場の 3 階東北隅にある第 2 図の 如き室で、床面積略 $270 \mathrm{~m}^{2}$, エロフインヒーターによる 熱風乾㷥機で作業時間中、

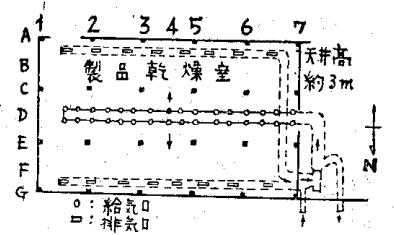

第 2 図 $30^{\circ} \mathrm{C}, 55 \%$ の空気調和を行つている。

\section{§3 実測結果とその検討}

a）製品倉庫。この倉庫は完成後数ケ月を経たもので あるが、室内は香だかなりの高湿状態を呈して招り、測 定に際しても、その湿潣の原因及び脱湿方法の検討に重 点を置いた。

今、各階の温湿度変動を此較すると日平均気温では 3 階のそれが、屋根版よりの灼込多の影響を受けて、最も 高く、2 階、1 階がこれて続き、各々の差は約 $1 \sim 2^{\circ} \mathrm{C}$ である。日平均湿度は 2 階〉 1 階〉 3 階の順机小さくな るが、2 階と 1 階の差、略 $1 \sim 2 \%$ に較べ、 1 階と 3 階

* 東京工業大学建築材料研究所
の差は約 8〜10\%とかなり大きくなつている。第 3 図に その測定例を揭げた。又、全測定期間を通ずる平均温湿 度及びこれより求めた水蒸気張力を比較すると第 1 表の 如くなり、2,3 階は 1 階に較べて水張の大きいととがわ

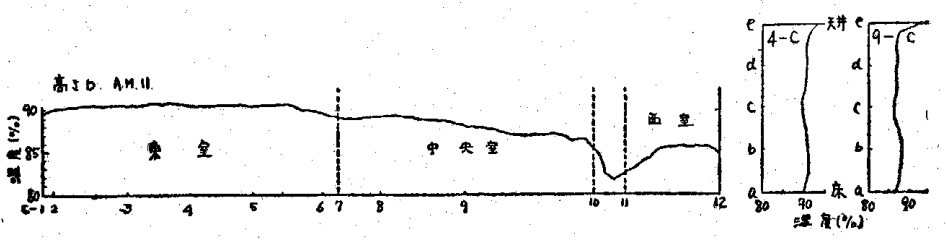

第 4 図

かる。1 1 階が比 較的乾燥してい るのは北面作 業時間中開放さ れる大きな出入 口があるためと 考えられる。 第 2 表

\begin{tabular}{|c|c|c|c|}
\hline \multirow{2}{*}{2 階 } & 平，聕 & 值 & (6月) \\
\hline & 温度 $\left({ }^{\circ} \mathrm{C}\right)$ & 湿度 $(\%)$ & $\begin{array}{c}\text { 水 張 } \\
(\mathrm{mmHg})\end{array}$ \\
\hline 東 & 24.8 & 91 & 21.4 \\
\hline 中央室 & 25.2 & 88 & 21.2 \\
\hline 西 & 24.4 & 78 & 17.9 \\
\hline
\end{tabular}

次に、水平方向の温湿度分布を 2 階各室の実測例飞就 てみると第 4 図、第 2 表の如くであつて、室面積に対し て開口部面積の比較的大きい西室が最子乾燥して和り、 中央室、東室の順序で大体西から東飞向つて湿潤度が増 大している。仿、各測定点の位置は第 1 図の記号飞従つ て表示した。即ち、第 4 図、水平分布の場合は 2 階 C列 の1から 12 までを高さbに就て測定したものであつ て、垂直分布は夫及東並に中央室の中心より一柱間だけ 南寄りの位置、4-C 及び 9-C 点江於ける測定結果であ る。この建物では 1 階を原料倉庫、2 階以上は製品倉庫 として使用されるが、中でも2 階東室は最も主要な庫室 とされているので、以下には主として、この階の測定結 果を述べる。測定は下の如き場合汇就て行つた。

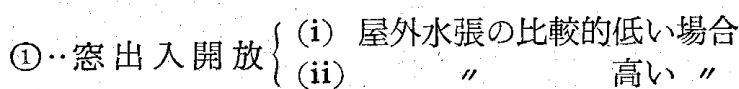

(2): 空出入口閉鎖 $\left\{\begin{array}{l}\text { (i) } \\ \text { (ii) " " 低W" }\end{array}\right.$

検討の対象とした日は空出入口の開閉を同一状㦔で三 日以上経過させた後、上記の分類に適合する日を選ん 


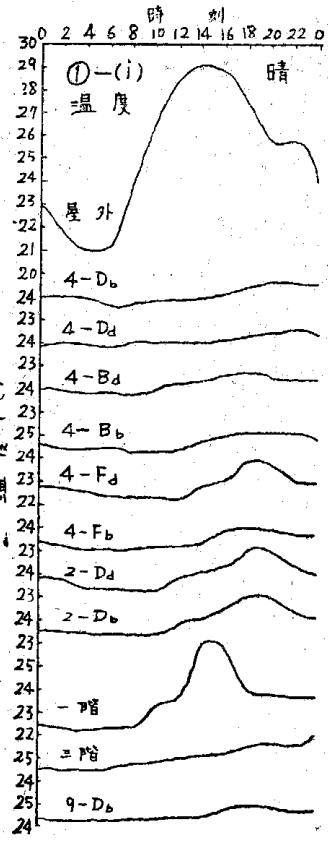

第，5図

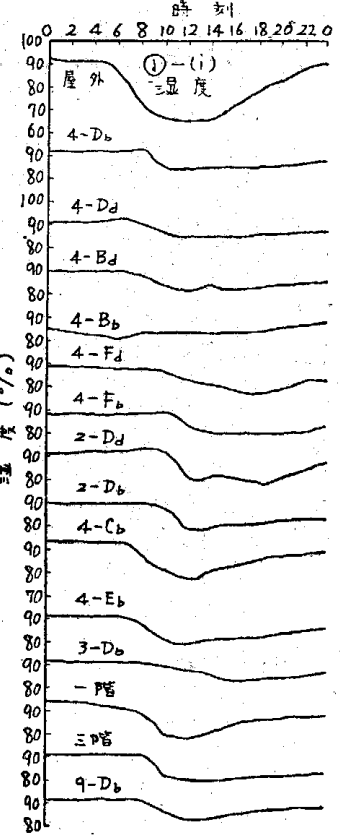

第 6 図

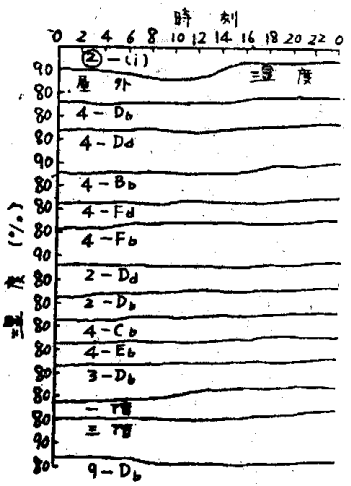

第 10 図

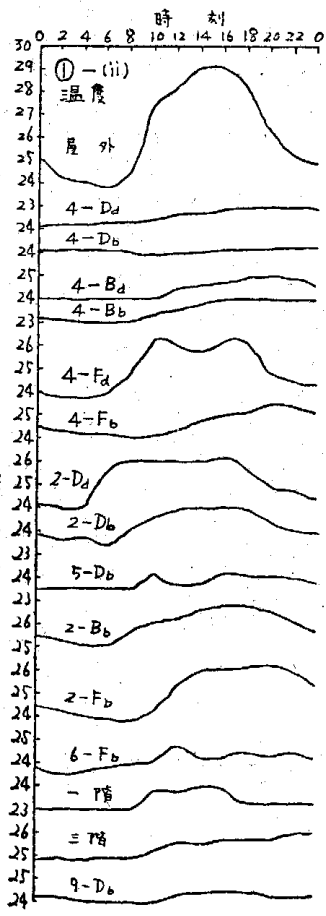

第 7 図

時 刘

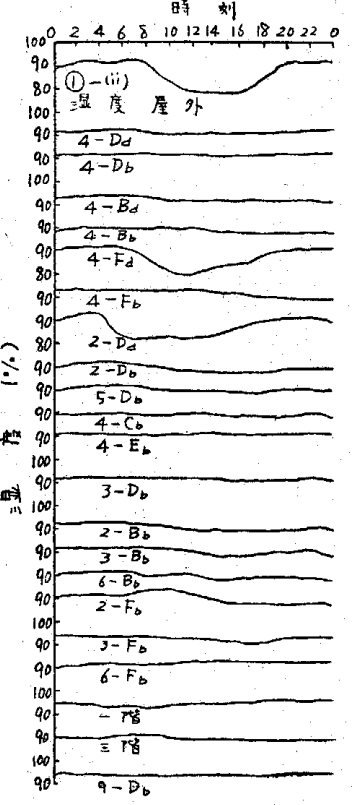

第 8 図

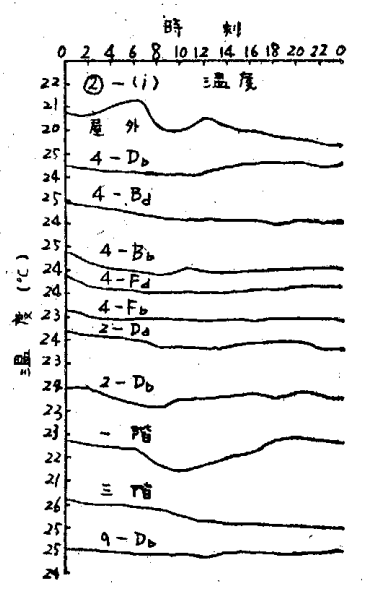

第 9 図

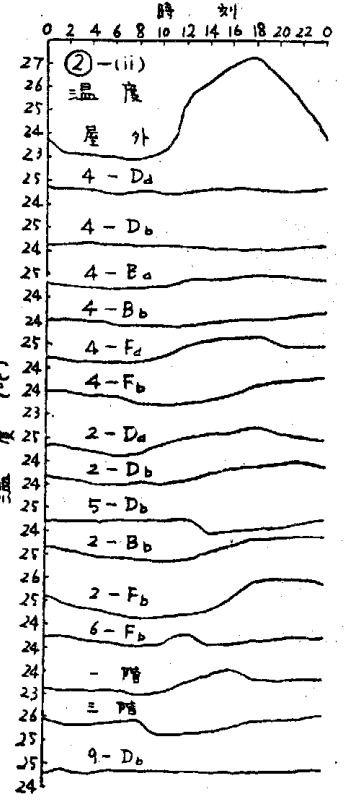

第 11 図

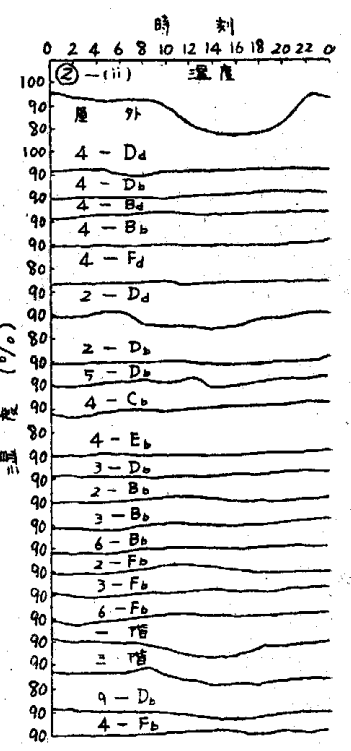

第 12 図

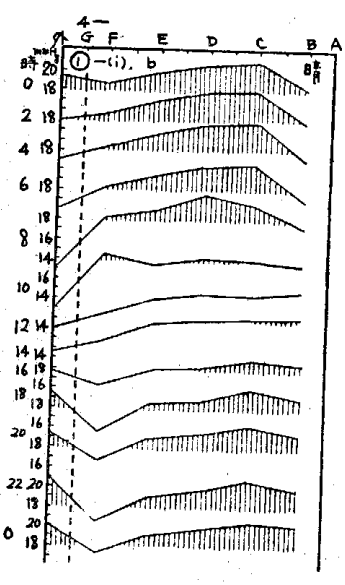

第 13 図

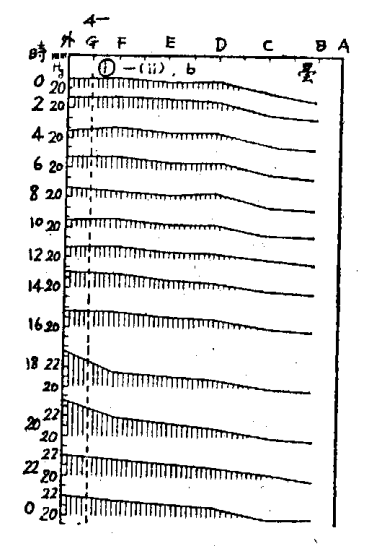

第 14 図

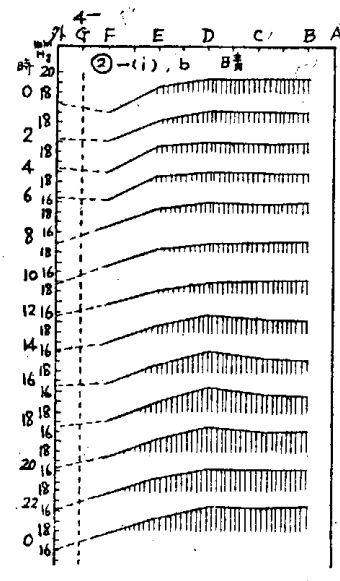

第 15 図

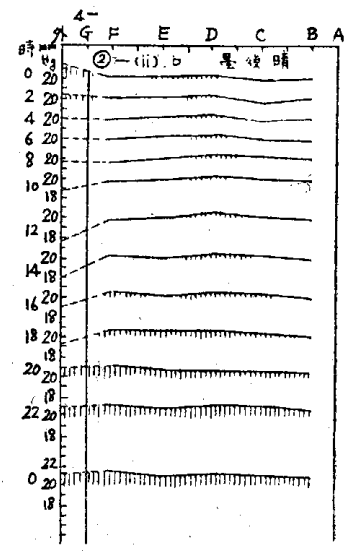

第 16 図 
だ。但し、(1)-(i) の測定例のみは、通常の使用状態、 即ち、午前 8 時 30 分より午後 5 時をで空を開放した日 が採つてある。前掲第 4 図もこの場合である。

今、夫々の場合飞就て、各部の温湿度変動の実測例を 示すと第 5 １2 図の通りであつて、これより、東室 4 列 高さ $b$ 亿於汁る時刻別水張分布を求めると第 13 16 図 の如くなる。左軸上飞は屋外水張を併記した。

(1)-(i)（第 13 図）のとき忤前 8 時 30 分開空と同 時臸内水張が低下し始めているのがみられる。向、10 時頃飞於ける $\mathrm{F}$ 点の值が $\mathrm{E}$ 点のそれより大きいのは、高 容であるため、空直下附近は屋外水張の影響が遟れて現 れるためと考光られる。

次に、(1)-(ii)（第 14 図）の場合は、屋外水張が比 較的高いため、空開放による著しい效果は見られない。 又、このときの室内湿度分布を第 17〜18 罒渴げた。 水平方向で管際より室の中央が、又垂直方向では天井 附近がやや高くなつている。

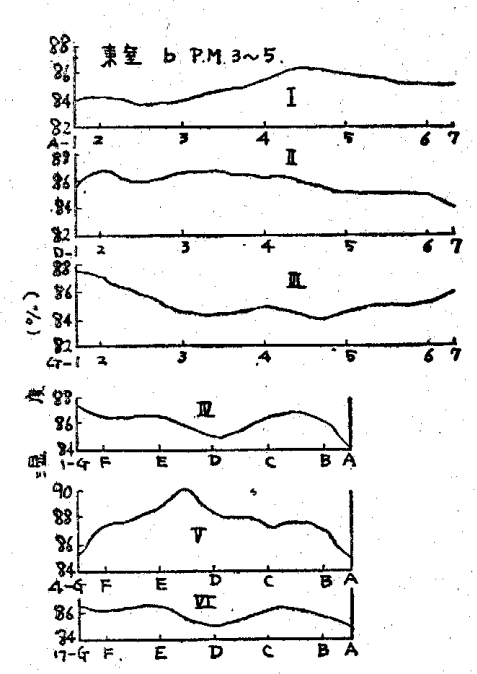

第 17 図

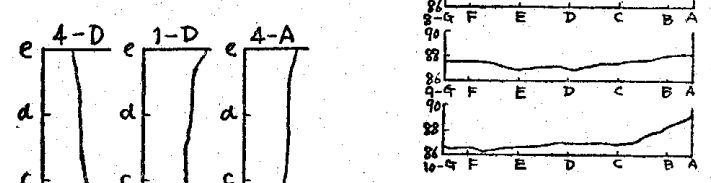

第 20 図

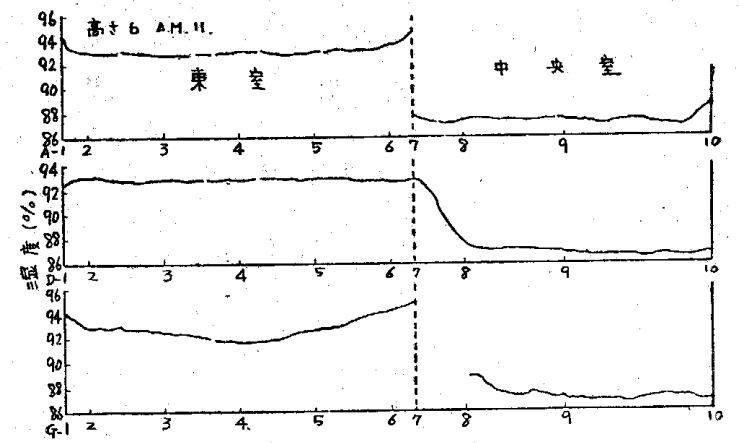

第 19 図
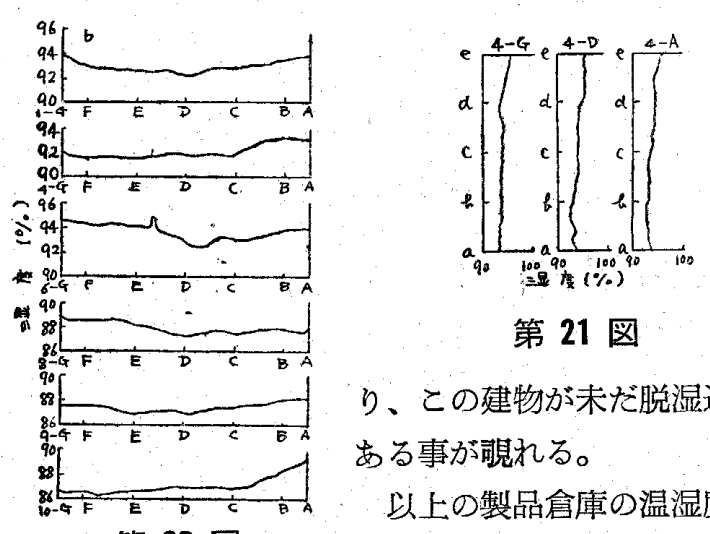

第 21 図

り、この建物が未だ脱湿過程に ある事が哯れる。

以上の製品倉庫の温湿度分布 及び変動に就て、種々実測検討 したところを要約すれば下の如くである。

1)：この実測例に於ける如き大規模な倉庫では、防火 的措置を含む適確な換気設備を必要とする。殊飞、隅角 部には高湿空気の停滞を生じ易く、容易に結露の原因と なるから換気経路に注意する。例党げ開口部にファンを 嵌込む位では不可。

2）:室内にコンクリート面を露出することをせず、木 材その他瀻維材料類で内装を施すととは室内湿度を低下 せしめる上と有効である。

3）：一般飞、倉庫建築は外壁の内外装並江䋓縁工事及 び附帯設徣行従来以上飞経費をさき、所謂、敷傷み、目 減又はサワテ等を或る程度不可抗力とする考光はやめる ベきであろろ。

4)：新築間もない倉庫の使用を早めるために、室内に 直接乾燥機攵は乾燥剤を設置する事る考光られるが、こ の実例の場合の如きは差当りこれを原料倉庫として活用 し、余㮃水分をこれに吸収させ、間接的飞脱湿を計る事 も一法である。但し、その際、入貨の種類並滞貨期間 そ就ては充分検討する必要があろう。因に、上記の措置

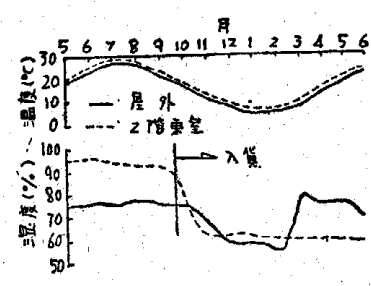

第 22 図 を行つた際の室内の脱湿過 程を第 22 図渴げた。

b) 製品乾燥室。この乾 燥室はエロフインヒーター 飞よる熱風乾燥機を採用し て括り、給排気口の位置は 第 2 図及び写真-1 㳘し 傍の湿度は中央部のそれに較べて約 $2 \%$ 大となつて和。 
た如くである。乾燥機 の運転は午前 7 時 30 分上り㡺食時の一時間 を除き午後 5 時迄行方 れ、夜間は出入口を閉 鎖して運転を休止す る。

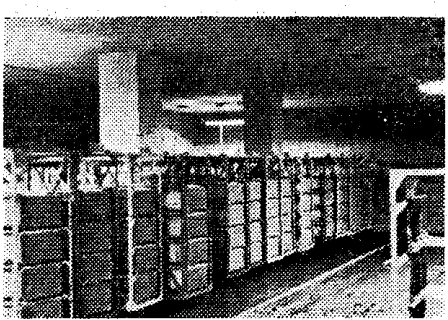

写真一1
作業中の湿度分布は、乾燥中の製品の量、出入口から の通風並に運搬車の出入等によつて多少の相異はある が、実測結果の一例を示すと，第 $23 ， 24$ 図の通りであ

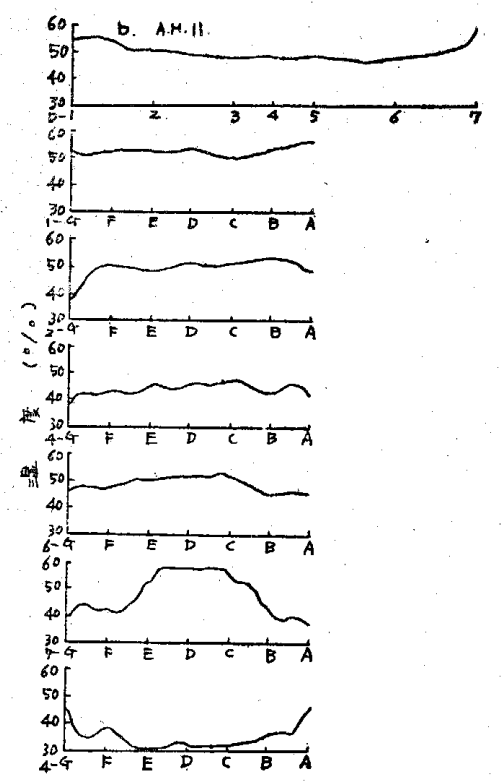

第 23 図

る。向、このときの隣接作業室の温湿度は $26^{\circ} \mathrm{C}, 67 \%$ で あつケ。同図に見られる様に、給排気口の位置が不適当 であるため短絡風路を生じ、肝心の製品を置く床面附近 は余り乾燥されていない。この場合は、寧ろ、側壁下部 に排気口を設け、所謂、下向換気法を採用すべきである

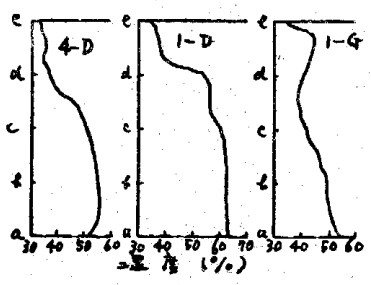

第 24 図

50

運転休止後、約 3 時間位より気温が除々に降下し、湿 度は漸次上昇を始めて、翌朝運転開始時の室内中央部の 温湿度は約 $32^{\circ} \mathrm{C} ， 73 \sim 75 \%$ であつた。

§4 結言 本報では電気测度計を用い、某タバコ製 造工場の倉庫等に於ける室内湿度分布及びその変動に関 し、種々実測検討したところを報告した。

近年、吾国で建築物の空気調和の普及に伴い、屋内 気候の問題も漸次重要視される様になつて来たが、一般 に倉庫建築のそれに関しては、未だ極めて関心が薄く、 米殼倉庫の如きも従来の土蔵造が今日尚、最上の構造型 式とされている現状である。現在の吾国の経済的事情よ り見て、ただらに本格的な機械的空気調和を考党るので なくても、屋外気像条件を最大限に活用した抜本的な倉 庫構造並に工法の実現が待望される。

擱筆に当り、電気湿度計の考案者であり、終始御指 導、御垂示を辱うした東京工業大学斉藤幸男教授、都立 大学工学部芹沢龍之介助教授及び斉藤研究室員松下昭氏 そ深謝の意を表すると共に、格別の御高配を賜つた日本 専売公社関係各位並に測定に尽力された飯田喜久雄氏に 厚く御礼申上げる。

[註］斎藤幸男、芹沢竜之介、松下昭、宮野秋彦；電 気湿度計飞よる屋内気候の研究（第 1 報）（測定器 及び測定方法)、日本建築学会関東支部第 20 回研究 発表会（昭.31.6）。 